\title{
PENGELUARAN WAJIB PAJAK DALAM PENINGKATAN PENERIMAAN PERPAJAKAN DI KANTOR PELAYANAN PAJAK PRATAMA MAKASSAR UTARA
}

\author{
Dharmawati \\ Universitas Ichsan Gorontalo,dharmawati_907@yahoo.com
}

\begin{abstract}
Abstrak
Kepatuhan Wajib Pajak dalam Meningkatkan Penerimaan Perpajakan di Kantor Pelayanan Pajak Pratama Makassar Utara. Tujuan penelitian ini adalah untuk mengetahui kepatuhan wajib pajak, penerimaan pajak, ketentuan umum dan prosedur perpajakan yang mempengaruhi kepatuhan wajib pajak setelah berlakunya Undang-Undang Nomor 16 Tahun 2009. Penelitian ini menggunakan jenis penelitian yuridis normatif. Sumber data primer dan sekunder serta tersier. Penelitian ini dianalisis secara kualitatif dengan mendeskripsikan secara deskriptif hasil data yang ada. Hasil penelitian menunjukkan bahwa kepatuhan wajib pajak di Kantor Pelayanan Pajak Pratama Makassar Utara belum memenuhi secara optimal, meskipun secara kuantitas penerimaan perpajakan meningkat dari tahun ke tahun. Penyebabnya adalah kurangnya pengetahuan dan pemahaman wajib pajak, sumber daya manusia perpajakan yang kurang memadai serta wajib pajak negatif mengenai ketentuan perpajakan belum merata. Sedangkan faktor yang mempengaruhi kepatuhan wajib pajak adalah faktor bahan hukum, faktor struktur hukum, faktor budaya hukum dan faktor sosialisasi perpajakan.

Kata Kunci: Kepatuhan terhadap Wajib Pajak; Penerimaan Pajak; Ketentuan Umum dan Tata Cara Perpajakan

Abstract

Taxpayer Compliance in Increasing Tax Revenue at the North Makassar Primary Tax Service Office. The purpose of this study is to determine taxpayer compliance, tax receipts, general provisions and tax procedures that affect taxpayer compliance after the enactment of Law Number 16 Year 2009. This study uses a juridical type of research normative. Primary and secondary data sources and tertiary. This research was analyzed qualitatively by describing descriptively the results of existing data. The results showed that the compliance of taxpayers at the North Makassar Primary Tax Service Office was not yet compliant optimally, although in quantity the tax revenue increased from year to year. The reason is the lack of knowledge and understanding of taxpayers, inadequate tax human resources as well as negative taxpayers regarding tax provisions have not been evenly distributed. While the factors that influence taxpayer compliance are legal substance factors, legal structure factors, legal cultural factors and tax socialization factors.
\end{abstract}

Keywords: Compliance with Taxpayers; Tax Receipts; General Provisions and Tax Procedures

\section{Pendahuluan}

Strategi perpajakan nasional diarahkan untuk mencapai kemandirian. Indonesia sendiri telah empat kali melakukan reformasi pajak, yaitu pertama pada tahun 1994, kedua pada tahun 2000, ketiga pada tahun 2007 dan yang keempat adalah pada tahun 2009.Selanjutnya, Pada tahun 2007 pemerintah kembali melakukan reformasi perpajakan dengan melakukan perubahan kembali terhadap beberapa undangundang perpajakan yaitu Undang-Undang Nomor 28 Tahun 2007 tentang Perubahan Ketiga Atas Undang-Undang Nomor 6 Tahun 1983 Tentang Ketentuan Umum Dan Tata Cara Perpajakan. Pada tahun 2009 dalam rangka untuk lebih memberikan 
keadilan dan meningkatkan pelayanan kepada Wajib Pajak dan untuk lebih memberikan kepastian hukum serta mengantisipasi perkembangan di bidang teknologi informasi dan perkembangan yang terjadi dalam ketentuan-ketentuan material di bidang perpajakan, pemerintah kembali melakukan perubahan terhadap Undang-Undang Nomor 6 Tahun 1983 tentang Ketentuan Umum dan Tata Cara Perpajakan sebagaimana telah beberapa kali diubah terakhir dari Undang-Undang Nomor 28 Tahun 2007 dengan Undang-Undang Nomor 16 Tahun 2009 Tentang Perubahan Keempat Atas Undang-Undang Nomor 6 Tahun 1983 Tentang Ketentuan Umum dan Tata Cara Perpajakan.

Perubahan Ketentuan Umum dan Tatacara Perpajakan, sebagaimana diuraikan dalam penjelasan umum Undang-Undang Nomor 16 Tahun 2009 dilakukan sejalan dengan perkembangan ekonomi, teknologi informasi, sosial, dan politik yang terjadi di Indonesia pada saat ini. Perubahan Ketentuan Umum dan Tata Cara Perpajakan juga bertujuan untuk lebih memberikan keadilan, meningkatkan pelayanan kepada Wajib Pajak, meningkatkan kepastian dan penegakan hukum, serta mengantisipasi kemajuan di bidang teknologi informasi dan perubahan ketentuan material di bidang perpajakan. Selain itu, perubahan tersebut juga dimaksudkan untuk meningkatkan profesionalisme aparatur perpajakan, meningkatkan keterbukaan administrasi perpajakan, dan meningkatkan kepatuhan sukarela Wajib Pajak. Rochmat Soemitro menyatakan bahwa :"Pajak ditinjau dari segi hukum memberikan hasil yang lain. Tinjauan pajak dari segi hukum lebih menitik beratkan kepada perikatan (verbitenis). ${ }^{1}$ Hukum pajak atau disebut juga sebagai hukum fiskal menurut Santoso Brotodihardjo adalah keseluruhan dari peraturan-peraturan yang meliputi wewenang pemerintah untuk mengambil kekayaan seseorang dan menyerahkannya kembali kepada masyarakat dengan melalui kas negara, sehingga merupakan bagian dari hukum publik, yang mengatur hubungan-hubungan hukum antara negara dan orang-orang atau badan-badan (hukum) yang berkewajiban membayar pajak (selanjutnya sering disebut wajib pajak).

Hukum pajak Materiil memuat norma-norma yang menerangkan keadaankeadaan, perbuatan-perbuatan dan peristiwa-peristiwa hukum yang harus dikenakan pajak, siapa yang harus dikenakan pajak, berapa besar pajaknya, atau segala sesuatu tentang timbulnya, besarnya dan hapusnya hutang pajak dan pula hubungan hukum antara pemerintah dengan wajib pajak.. Hukum pajak positif baik yang bersifat materiil maupun yang bersifat formil, harus dilandasi filsafat keadilan. Harus disadari bahwa pemajakan berarti dalam batas-batas tertentu mengorbankan kepentingan seseorang demi kepentingan umum. Dalam penerapannya Wajib Pajak diharapkan untuk lebih meningkatkan pemahaman terhadap perubahan UndangUndang Ketentuan Umum Perpajakan tersebut agar dapat meningkatkan kesadaran akan arti penting pajak. Namun demikian disadari bahwa dalam pelaksanaan Undang-Undang Nomor 16 Tahun 2009 tentang Perubahan Keempat Atas UndangUndang Nomor 6 Tahun 1983 Tentang Ketentuan Umum dan Tata Cara Perpajakan ada faktor-faktor yang mempengaruhi tingkat Kepatuhan dan Penerimaan Pajak baik dari petugas pajak sebagai contoh kurangnya sosialisasi terhadap peraturan tersebut maupun dari wajib pajak yaitu Masih rendahnya pemahaman masyarakat akan

\footnotetext{
${ }^{1}$ H. R. Soemitro, (1988). Pajak Ditinjau Dari Segi Hukum. Eresco. Bandung, hal. 29
} 
Ketentuan Umum Perpajakan dan tingkat kesadaran masyarakat akan arti penting pajak ${ }^{2}$.

Oleh karena itu, penulis akan menganalisa Perubahan Ketentuan Umum Dan Tata Cara Perpajakan dalam rangka Peningkatan Kepatuhan Wajib Pajak dan Peningkatan Penerimaan Pajak. Berikut ini penulis menggambarkan kerangka piker ke dalam bentuk diagram untuk membantu penulis dalam menganalisa tujuan penelitian.

\section{Metode}

Jenis penelitian ini adalah penelitian normatif dan empiris yang melakukan pengkajian terhadap norma dan asas hukum di bidang perpajakan. Pendekatan yang digunakan adalah pendekatan perundang-undangan tentang Ketentuan Umum dan Tata Cara Perpajakan dan pendekatan kasus. Data yang digunakan adalah data primer dan data sekunder. Data sekunder diperoleh dari hasil observasi dan penilaian lapangan. Bahan hukum yang digunakan dalam penelitian ini adalah adalah bahan hukum primer, bahan hukum sekunder dan bahan hukum tersier. Bahan hukum primer terdiri dari peraturan perundang-undangan terkait dengan Ketentuan Umum dan Tata Cara Perpajakan. Bahan hukum sekunder berupa literatur yaitu buku, jurnal dan artikel terkait. Data yang diperoleh akan dianalisis secara deskriptif kualitatif.

\section{Hasil dan Pembahasan}

3.1. Kepatuhan Wajib Pajak Dan Peningkatan Penerimaan Pajak Setelah Berlakunya Undang-Undang Nomor 16 Tahun 2009 Tentang Ketentuan Umum Dan Tata Cara Perpajakan.

Kepatuhan wajib pajak dan peningkatan penerimaan pajak setelah berlakunya UU Nomor 16 Tahun 2009, maka berikut ini penulis menyajikan jumlah wajib pajak yang terdaftar di enam (6) kecamatan diwilayah kerja KPP Pratama Makassar Utara sebagai berikut :

Tabel 1. Luas Wilayah dan Jumlah Wajib Pajak per Kecamatan di KPP Pratama Makassar Utara sampai tahun 2019

\begin{tabular}{|c|l|c|c|}
\hline No & \multicolumn{1}{|c|}{ Wilayah } & $\begin{array}{c}\text { Luas Wilayah } \\
\text { (Ha) }\end{array}$ & Jumlah WP \\
\hline 1. & Kecamatan Biringkanaya & 3.007 & 21.047 \\
\hline 2. & Kecamatan Tamanlanrea & 2.873 & 12.302 \\
\hline 3. & Kecamatan Tallo & 694 & 14.125 \\
\hline 4. & Kecamatan Ujung Tanah & 84 & 4.402 \\
\hline 5. & Kecamatan Wajo & 206 & 26.699 \\
\hline 6. & Kecamatan Bontoala & 108 & 10.690 \\
\hline
\end{tabular}

\footnotetext{
${ }^{2}$ I. Suhardi, (2016). Eksistensi Undang-Undang Nomor 6 Tahun 1983 tentang Ketentuan Umum dan Tata Cara Perpajakan Dalam Pembangunan Sistem Hukum Pajak Nasional (doctoral dissertation, universitas airlangga).
} 


\begin{tabular}{|c|c|c|}
\hline Jumlah & $\mathbf{6 . 9 7 2}$ & $\mathbf{8 9 . 2 6 5}$ \\
\hline
\end{tabular}

Sumber: Pengolahan Data dan Informasi KPP Pratama Makassar Utara

Berikut disajikan tabel penerimaan pajak pada KPP Pratama Makassar Utara tahun 2015-2019

Tabel 2. Penerimaan Pajak Pada KPP Pratama Makassar Utara. Tahun 2015 - 2019

\begin{tabular}{|c|c|c|c|}
\hline Tahun & Rencana & Realisasi & $\begin{array}{c}\text { Persen } \\
\text { (\%) }\end{array}$ \\
\hline 2015 & Rp. 426.776.195.000 & Rp. 440.727.780.098 & 1003,27 \\
\hline 2016 & Rp. 439.151.690.000 & Rp. 444.421.510.646 & 101,20 \\
\hline 2017 & Rp. 463.883.692.000 & Rp. 493.371.572.898 & 10636 \\
\hline 2018 & Rp. 631.054.153.000 & Rp. 625.374.665.381 & 99,10 \\
\hline 2019 & Rp. 903.223.741.000 & Rp. 887.417.325.234 & 98,25 \\
\hline
\end{tabular}

Sumber: KPP Pratama Makassar Utara, Juli 2019

Tabel diatas nampak dengan jelas menunjukkan bahwa penerimaan pajak di KPP Pratama Makassar mengalamai peningkatan dari tahun ketahun. Tingkat kepatuhan Wajib Pajak yang semakin tinggi tentu saja akan berkaitan dengan bertambah besarnya jumlah penerimaan pajak.. Penerimaan negara dari sektor pajak setiap tahunnya mengalami peningkatan, hal tersebut dapat dilihat dari APBN baik dari perencanaan maupun realisasi penerimaannya. Hal tersebut nampak dari tabel berikut ini:

Tabel 3. Rencana dan Realisasi Penerimaan Pajak Dalam APBN Tahun 2015 - 2019

\begin{tabular}{|l|c|c|c|}
\hline No & Tahun & Rencana & Realisasi \\
\hline 1 & 2015 & 492 Trilliun & 491 Trilliun \\
\hline 2 & 2016 & 534 Trilliun & 559 Trilliun \\
\hline 3 & 2017 & 803 Trilliun & 712 Trilliun \\
\hline 4 & 2018 & 911 Trilliun & 841 Trilliun \\
\hline 5 & 2019 & 1.285 Trilliun & 1.066 Trilliun \\
\hline
\end{tabular}

Sumber: Seksi Pengolahan Data dan Informasi

Pajak mempunyai peran yang sangat dominan dalam APBN, hal ini nampak dari perbandingan jumlah penerimaan pajak yang semakin lama semakin meningkat dibandingkan dengan jumlah penerimaan dalam negeri lainnya hal ini nampak dari 
realisasi APBN sebelum dan sesudah berlakunya Undang-Undang Nomor 16 Tahun 2009. Pengetahuan Wajib pajak tentang Ketentuan Umum dan Tata Cara Perpajakan yang lama (UU No. 28 tahun 2007), dengan pertanyaan apakah saudara tahu tentang UU No.28 tahun 2007. Dengan jumlah responden 50 orang yang terdiri dari 25 orang Wajib Pajak Badan dan 25 orang Wajib Pajak Perseorangan.

Tabel 4.Pengetahuan Wajib Pajak Tentang Ketentuan Umum Dan Tata Cara Perpajakan Yang Lama

\begin{tabular}{|c|l|c|c|c|c|}
\hline \multirow{2}{*}{ No } & \multirow{2}{*}{ Jenis Wajib Pajak } & \multicolumn{4}{|c|}{ Jawaban } \\
\cline { 3 - 6 } & & Tahu & Persentasi & Tidak & Persentasi \\
\hline 1 & WP Perseorangan & 19 & $76 \%$ & 6 & $24 \%$ \\
\hline 2 & WP Badan & 23 & $92 \%$ & 2 & $8 \%$ \\
\hline
\end{tabular}

Sumber: Data primer yang telah diolah, 2019

Tabel diatas menunjukan Wajib Pajak Perseorangan sekitar 76\% (19 orang), sedangkan sisanya 24\% (6 orang) menjawab tidak tahu. Sedangkan terhadap WP Badan hampir 92\% (23 orang) menyatakan tahu dan Sisanya 8\% (2 orang) menyatakan tidak mengetahuinya.

Tabel 5 .Tentang Pengetahuan Responden atas UU No. 16 Tahun 2009

\begin{tabular}{|c|c|c|c|c|c|}
\hline \multirow{2}{*}{ No } & \multirow{2}{*}{ Jenis Wajib Pajak } & \multicolumn{4}{|c|}{ Jawaban } \\
\cline { 3 - 6 } & & Tahu & Persentasi & Tidak & Persentasi \\
\hline 1 & WP Perseorangan & 11 & $44 \%$ & 14 & $56 \%$ \\
\hline 2 & WP Badan & 18 & $72 \%$ & 7 & $28 \%$ \\
\hline
\end{tabular}

Sumber: Data primer yang telah diolah, 2019

Dari data kuantitatif pada tabel diatas ternyata kebanyakan WP Perseorangan tidak mengetahui adanya UU Nomor 16 Tahun 2009 yaitu sekitar 56\% (14 orang), sedangkan sisanya 44\% (11 orang) menjawab tidak tahu. Sedangkan terhadap Wajib Pajak Badan hampir 72\% (18 orang) menyatakan tahu akan undang-undang ketentuan umum dan tata cara perpajakan yang baru dan Sisanya 28\% (7 orang) menyatakan tidak mengetahuinya. Pernyataan dilanjutkan tentang pengetahuan responden terhadap pokok-pokok perubahan UU Nomor 16 Tahun 2009, maka hasilnya nampak dalam tabel 6 di bawah ini: 
Tabel 6.Pengetahuan Responden Terhadap Pokok-Pokok Perubahan UU Nomor 16 Tahun 2009

\begin{tabular}{|c|c|c|c|c|c|}
\hline \multirow{2}{*}{ No } & \multirow{2}{*}{ Jawaban } & \multicolumn{4}{|c|}{ Jenis Wajib Pajak } \\
\cline { 3 - 6 } & $\begin{array}{c}\text { Wajib Pajak } \\
\text { Perseorangan }\end{array}$ & $\begin{array}{c}\text { Persentas } \\
\text { i }\end{array}$ & $\begin{array}{c}\text { WP } \\
\text { Badan }\end{array}$ & $\begin{array}{c}\text { Persenta } \\
\text { si }\end{array}$ \\
\hline 1. & Benar & 2 & $8 \%$ & 5 & $20 \%$ \\
\hline 2. & Salah & 5 & $20 \%$ & 5 & $20 \%$ \\
\hline 3. & Tidak Tahu & 18 & $72 \%$ & 15 & $60 \%$ \\
\hline \multicolumn{2}{|c|}{ Total } & $\mathbf{2 5}$ & $\mathbf{1 0 0} \%$ & $\mathbf{2 5}$ & $\mathbf{1 0 0} \%$ \\
\hline
\end{tabular}

Sumber: Data primer yang telah diolah, 2019

Data tersebut menunjukan pengetahuan responden terhadap pokok-pokok perubahan Undang-Undang Nomor 16 Tahun 2009 Tentang Ketentuan Umum dan Tata Cara Perpajakan masih sangat rendah. Wajib Pajak Badan hanya 20 \% (5 orang) yang menjawab benar sedangkan sisanya 20\% (5 orang) menjawab tapi salah dan 60\% (15 orang) menjawab tidak tahu, Wajib Pajak Perseorangan lebih rendah yaitu hanya sekitar $8 \%$ (2 orang) yang menjawab benar, sedangkan sisanya 20\% (5 orang) menjawab salah dan 72\% (18 orang) menjawab tidak tahu.Tentang Persepsi Responden terhadap Ketentuan Umum Dan Tata Cara Perpajakan Yang Lama.

Tabel 7.Persepsi Wajib Pajak Terhadap Ketentuan Umum

Dan Tata Cara Perpajakan yang Lama

\begin{tabular}{|c|c|c|c|c|c|}
\hline \multirow{2}{*}{ No } & \multirow{2}{*}{ Jawaban } & \multicolumn{4}{|c|}{ Jenis Wajib Pajak } \\
\cline { 3 - 6 } & & $\begin{array}{c}\text { WP } \\
\text { Perseorangan }\end{array}$ & Persentasi & $\begin{array}{c}\text { WP } \\
\text { Badan }\end{array}$ & Persentasi \\
\hline 1. & Rumit & 21 & $84 \%$ & 20 & $80 \%$ \\
\hline 2. & Sedang & 1 & $4 \%$ & 4 & $16 \%$ \\
\hline 3. & Mudah & 3 & $12 \%$ & 1 & $4 \%$ \\
\hline \multicolumn{2}{|c|}{ Total } & $\mathbf{2 5}$ & $\mathbf{1 0 0} \%$ & $\mathbf{2 5}$ & $\mathbf{1 0 0} \%$ \\
\hline
\end{tabular}

Sumber: Data primer yang telah diolah, 2019

Ketika responden ditanya tentang persepsi atau penilaian responden terhadap ketentuan umum dan tata cara perpajakan yang lama, dari jawaban responden (seperti terlihat di tabel 8) ternyata hampir kebanyakan responden menyatakan rumit yaitu di atas $80 \%$ dari seluruh responden. Tentang Persepsi Responden Terhadap KUP Yang Baru sebagai berikut; 
Tabel 8. Persepsi Wajib Pajak Terhadap Ketentuan Umum Dan Tata Cara Perpajakan

\begin{tabular}{|c|c|c|c|c|c|}
\hline \multirow{2}{*}{ No } & \multirow{2}{*}{ Jawaban } & \multicolumn{4}{|c|}{ Jenis Wajib Pajak } \\
\hline & & $\begin{array}{l}\text { Wajib Pajak } \\
\text { Perseorangan }\end{array}$ & Persentasi & $\begin{array}{c}\text { WP } \\
\text { Badan }\end{array}$ & Persentasi \\
\hline 1. & Rumit & 8 & $32 \%$ & 12 & $48 \%$ \\
\hline 2. & Sedang & - & - & 1 & $4 \%$ \\
\hline 3. & Mudah & 2 & $8 \%$ & 1 & $4 \%$ \\
\hline \multicolumn{2}{|c|}{ Tidak Menjawab } & 15 & $60 \%$ & 11 & $44 \%$ \\
\hline & Total & 25 & $100 \%$ & 25 & $100 \%$ \\
\hline
\end{tabular}

Sumber: Data primer yang telah diolah, 2019

Ketika responden ditanya tentang persepsi atau penilaian responden terhadap Ketentuan Umum Dan Tata Cara Perpajakan yang baru, diperoleh data bahwa yang menyatakan rumit yaitu sekitar 32\% (8 orang) responden Wajib Pajak Perseorangan menyatakan rumit, 8\%(2 orang) menyatakan mudah dan sisanya 60\% (15 orang) menyatakan tidak menjawab/ tidak tahu. Sedangkan Wajib Pajak Badan 48\% (12 orang) menyatakan mudah, 4\% (1 orang) menyatakan sedang, 4\% (1 orang) menyatakan mudah dan 44\% (11 orang) menyatakan tidak menjawab/ tidak tahu. Alasan Responden Mematuhi Aturan-Aturan Pajak sebagai berikut;

Tabel 9. Persepsi Wajib Pajak Mengenai Alasan Responden Mematuhi Aturan-Aturan Pajak

\begin{tabular}{|c|c|c|c|}
\hline No & Indikator Jawaban & $\begin{array}{c}\text { WP Perseorangan Dan WP } \\
\text { Badan (Responden) }\end{array}$ & $\begin{array}{c}\text { Skor } \\
\text { Persentasi }\end{array}$ \\
\hline 1. & Terpaksa & 40 & $80 \%$ \\
\hline 2. & Kewajiban & 10 & $20 \%$ \\
\hline \multicolumn{2}{r|}{ Total } & 50 & $100 \%$ \\
\hline
\end{tabular}

Sumber: Data primer yang telah diolah, 2019

Tabel diatas diperoleh hasil yaitu sebagian besar responden menyatakan bahwa mereka terpaksa karena tidak mau dapat masalah sekitar 80\% (40 orang), sisanya menyatakan karena kewajiban sebagai warga negara 20\% (10 orang). Dari hasil penelitian yang dilakukan belum nampak adanya sebuah perubahan atau peningkatan yang cukup berarti dari adanya ketentuan umum perpajakan yang baru ini. 


\subsection{Faktor-Faktor Yang Mempengaruhi Kepatuhan Wajib Pajak Dan Penerimaan Pajak Setelah Berlakunya Undang-Undang Nomor 16 Tahun 2009 Tentang Ketentuan Umum Dan Tata Cara Perpajakan \\ 1. Faktor Substansi Hukum}

Faktor substansi hukum yang dimaksud oleh penulis dalam penelitian ini adalah faktor kebijakan penegakan hukum dalam upaya peningkatan kepatuhan Wajib Pajak. Pajak telah menjadi instrumen fiskal yang penting dalam perekonomian suatu negara atau pemerintah. Tanpa pajak, negara tidak mendapatkan pemasukan dan tidak akan mampu membiayai jalannya pemerintahan. Bila pendapatan negara dari pajak tidak didorong secara optimal ada lobang dalam pemasukan pemerintah, artinya peluang terjadinya defisit akan semakin terbuka. Meningkatnya jumlah Wajib Pajak dan pemahaman akan hak dan kewajibannya dalam melaksanakan peraturan perundang-undangan perpajakan tidak dapat dihindarkan dan memerlukan pengaturan yang adil dan bijaksana dengan prosedur dan proses yang cepat dan sederhana, karenanya diperlukan suatu sistem yang mampu menciptakan keadilan dan kepastian hukum.

Diharapkan dengan reliable, kepercayaan dunia usaha, khususnya bagi Wajib Pajak, baik warga negara Indonesia maupun pihak asing semakin meningkat terhadap hukum di bidang perpajakan yang berlaku di Indonesia, sehingga mereka merasa terayomi dan terlindungi secara hukum serta bersedia menanamkan modalnya dan berdagang di Negara Republik Indonesia. Hak-hak Wajib Pajak harus secara berkesinambungan diperhatikan dan dilindungi secara hukum, dan ketentuan yang dikeluarkan yang berhubungan dengan perpajakan harus lebih responsif terhadap Wajib Pajak yang benar dan atau beritikad baik.Untuk meningkatkan kepatuhan wajib pajak dalam rangka meningkatkan penerimaan pendapatan negara dari sektor pajak yang dilakukan pemerintah terlihat dari berbagai kebijakan antara lain Sunset Policy. Sunset Policy adalah kebijakan pemberian fasilitas perpajakan, yang berlaku hanya di tahun 2008, dalam bentuk penghapusan sanksi administrasi perpajakan berupa bunga yang diatur dalam Pasal 37A Undang-Undang Nomor 16 Tahun 2009 tentang ketentuan umum dan tata cara perpajakan.

Pasal 37 A UU KUP juga memberikan jaminan "tidak dilakukan pemeriksaan pajak, kecuali; (a) Terdapat data atau keterangan yang menyatakan bahwa Surat Pemberitahuan yang disampaikan Wajib Pajak tidak benar, sesuai pasal 29 UU KUP; (b)Menyatakan lebih bayar, sesuai Pasal 17 UU KUP. Pasal 3 Peraturan Menteri Keuangan Nomor 18/PMK.03/2008 tanggal 6 Pebruari 2008 menyebutkan bahwa pemberian penghapusan sanksi administrasi ini dilakukan dengan cara tidak menerbitkan Surat Tagihan Pajak; (a) Kebijakan sunset policy yang telah terbukti meningkatkan jumlah wajib pajak, dengan kebijakan dari pemerintah diperpanjang hingga Februari 2009 dengan maksud agar lebih banyak lagi wajib pajak yang terdaftar yang pada akhirnya dapat meningkatkan penerimaan pajak; (b)Selain dengan kebijakan Sunset Policy pemerintah juga melakukan berbagai upaya-upaya untuk meningkatkan kepatuhan wajib pajak yaitu; (1)Secara persuasif diberikan himbauan (melalui surat atau iklan media massa) agar Wajib Pajak patuh; (2)Secara represif dikenakan sanksi administrasi atas keterlambatan lapor/tidak lapor sebesar $2 \%$ perbulan dari jumlah pajak yang harus dibayar dan dikenakan denda Rp. 1.000.000,- (satu juta Rupiah) untuk SPT tahunan badan, Rp. 500.000,- (lima ratus ribu 
rupiah) untuk SPT PPN dan Rp. 100.000,- untuk SPT PPh; (3)Secara kontinyu dan periodik diadakan penyuluhan ke wajib pajak untuk meningkatkan kepatuhan dan kesadaran pajak.

\section{Faktor Struktur Hukum.}

Faktor struktur hukum yang dimaksud oleh penulis dalam penelitian ini yaitu pihak-pihak yang membentuk maupun menerapkan hukum baik itu birokrat perpajakan (petugas pajak) maupun Wajib Pajak sendiri terhadap pengaruh kepatuhan Wajib Pajak. Humphreys menyatakan bahwa pelayanan publik dapat didefinisikan sebagai pelayanan yang utama atau lengkap yang dibiayai dari pajak. ${ }^{3}$ Pelayanan publik juga termasuk semua hal yang menyangkut manajemen publik baik oleh pemerintah pusat maupun pemerintah daerah seperti jaminan kesehatan, pendidikan, pertahanan, dan penegakan hukum. Kepentingan publik tidak lagi dipandang sebagai agregasi kepentingan pribadi, melainkan sebagai hasil dialog dan keterlibatan publik dalam mencari nilai bersama dan kepentingan bersama. Dibeberapa negara pernah dikembangkan apa yang disebut "citizen charta" yang merangkum hak-hak apa saja yang dimiliki warga sebagai pembayar pajak dari negara. Warga tidak lagi dilihat sebagai abdi, melainkan sebagai pelanggan yang karena pajak yang dibayarkannya mempunyai hak atas layanan dalam jumlah tertentu dan kualitas tertentu pula. ${ }^{4}$ Pembayar pajak berhak mendapatkan jasa layanan pemerintah melalui fungsi pelayanan publik yang standar. Pelayanan adalah suatu proses bantuan kepada orang lain dengan cara-cara tertentu yang memerlukan kepekaan dan hubungan interpersonal agar tercipta kepuasan dan keberhasilan. ${ }^{5}$

Muhammad Syafiqurrahman dan Sri Suranta meneliti tentang faktor-faktor yang mempengaruhi wajib pajak terhadap kepatuhan pembayaran pajak restoran di Surakarta menunjukkan bahwa variabel pelayanan tidak berpengaruh signifikan terhadap kepatuhan wajib pajak dikarenakan kurangnya penyuluhan yang dilakukan.Berdasarkan uraian diatas dapat disimpulkan kualitas pelayanan yang baik kepada Wajib Pajak akan dapat meningkatkan kepatuhan wajib pajak dalam memenuhi kewajiban perpajakan, demikian juga sebaliknya.Kurangnya pemahaman Wajib Pajak terhadap System Self Assessment. System Self Assessment merupakan sistem pemungutan pajak yang mana besarnya pajak dihitung sendiri oleh wajib pajak. ${ }^{6}$

Hasil penelitian Rika Anggraeni, membuktikan bahwa relatif rendahnya kesadaran pengisian SPT Tahunan merupakan faktor yang secara signifikan menyebabkan Wajib Pajak tidak mengisi sendiri SPT Tahunan. Hal ini menunjukkan bahwa rendahnya pemahaman self assessment system akan berpengaruh terhadap kepatuhan wajib pajak. ${ }^{7}$ Hasil penelitian Chusnul Chotimah, yang dilakukan terhadap Wajib Pajak menunjukkan bahwa pemahaman terhadap system self assessment berpengaruh positif signifikan terhadap kepatuhan Wajib Pajak dalam

\footnotetext{
${ }^{3}$ Humphreys (1998). Pelayanan Publik Sebagai Pelayanan Utama yang Dibiayai Dari Pajak.

${ }^{4}$ Saleh dan Muluk, (2006). Hak Atas Layanan Sebagai Pembayar Pajak.

${ }^{5}$ Boediono, Niluh (2006) .Pelayanan Memerlukan Kepekaan dan Hubungan Interpersonal Agar Tercipta Kepuasan dan Keberhasilan.

${ }^{6}$ Muhammad dan Sri Suranta, (2006).Tingkat Pendidikan Tidak Berpengaruh Terhadap Kepatuhan Wajib Pajak Dalam Membayar Pajak Restoran, Surakarta.

${ }^{7}$ Rika Anggraeni, (2007), Kesadaran Pengisian SPT Tahunan.
} 
melaksanakan kewajiban perpajakan pajak penghasilan. Jadi semakin tinggi tingkat pemahaman Wajib Pajak terhadap self assessment system akan semakin meningkat pula kepatuhan Wajib Pajak dalam membenahi kewajiban perpajakan sehingga akan meningkat pula penerimaan pajak. ${ }^{8}$ Chusnul Chotimah menemukan bahwa tidak terdapat pengaruh kesadaran terhadap sanksi perpajakan terhadap kepatuhan Wajib Pajak dalam melaksanakan kewajiban perpajakan pajak penghasilan. Hasil penelitian Sulud Kahono, juga membuktikan bahwa sikap wajib pajak tentang sanksi denda PBB berpengaruh signifikan terhadap kepatuhan Wajib Pajak. Jadi persepsi Wajib Pajak terhadap sanksi perpajakan berpengaruh terhadap kepatuhan Wajib Pajak. Penelitian Muhammad dan Sri Suranta, menemukan bahwa tingkat pendidikan tidak berpengaruh terhadap kepatuhan wajib pajak dalam membayar pajak restoran di Surakarta. Hal ini disebabkan karena responden merasa kurangnya penyuluhan yang dilakukan dan pemerintah tidak transparan.

Kegiatan sosialisasi bagi Wajib Pajak baru bertujuan untuk meningkatkan pemahaman dan kepatuhan untuk memenuhi kewajiban perpajakannya, khususnya bagi mereka yang belum menyampaikan SPT dan belum melakukan penyetoran pajak untuk yang pertama kali. Sedangkan kegiatan sosialisasi bagi Wajib Pajak terdaftar bertujuan untuk menjaga komitmen Wajib Pajak untuk terus patuh.

\section{Kesimpulan}

Kepatuhan Wajib Pajak dan Peningkatan Penerimaan Pajak di KPP Pratama Makassar Utara setelah adanya Undang-Undang Nomor 16 Tahun 2009 tentang Perubahan Ketentuan Umum dan Tata Cara Perpajakan, ternyata belum patut terlaksana secara optimal walaupun penerimaan pajak meningkat dari tahun ke tahun. Hal ini dikarenakan masih rendahnya pengetahuan dan pemahaman Wajib Pajak, sumber daya manusia dan pelayanan petugas pajak dan kurangnya sosialisasi perpajakan serta persepsi negatif Wajib Pajak terhadap ketentuan umum perpajakan yang berlaku.Faktor-faktor yang mempengaruhi Kepatuhan Wajib Pajak dan Peningkatan Penerimaan Pajak setelah adanya Undang-Undang Nomor 16 Tahun 2009 sebagai Implikasi dari Perubahan Ketentuan Umum Dan Tata Cara Perpajakan antara lain: Faktor Substansi Hukum, Faktor Struktur Hukum, Faktor Budaya Hukum Masyarakat dan Faktor Sosialisasi Perpajakan.

\section{REFERENSI}

Boediono, Niluh (2006), Pelayanan Memerlukan Kepekaan dan Hubungan Interpersonal. Chusnul Chotimah, (2007), Sanksi Perpajakan Terhadap Kepatuhan Wajib Pajak Dalam Melaksanakan Kewajiban Perpajakan Pajak Penghasilan.

H.R. Soemitro, (1988, Pajak Ditinjau Dari Segi Hukum, Bandung: Eresco.

I. Suhardi, (2016). Eksistensi Undang-Undang Nomor 6 Tahun 1983 tentang Ketentuan Umum dan Tata Cara Perpajakan Dalam Pembangunan Sistem Hukum Pajak Nasional, Disertasi Universitas Airlangga

Muhammad dan Sri Suranta, (2006).Tingkat Pendidikan Tidak Berpengaruh Terhadap Kepatuhan Wajib Pajak Dalam Membayar Pajak Restoran, Surakarta.

\footnotetext{
${ }^{8}$ Chusnul Chotimah, (2007), Sanksi Perpajakan Terhadap Kepatuhan Wajib Pajak dalam Melaksanakan Kewajiban Perpajakan Pajak Penghasilan.
} 
Rika Anggraeni, (2007), Kesadaran pengisian SPT Tahunan.

Saleh dan Muluk, (2006). Hak Atas Layanan Sebagai Pembayar Pajak. 